\title{
Article \\ Chemically Crosslinked Methylcellulose Substrates for Cell Sheet Engineering
}

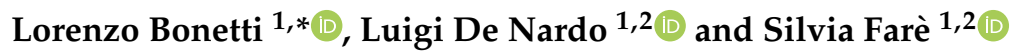 \\ 1 Department of Chemistry, Materials and Chemical Engineering “G. Natta”, Politecnico di Milano, Via Luigi \\ Mancinelli 7, 20131 Milan, Italy; luigi.denardo@polimi.it (L.D.N.); silvia.fare@polimi.it (S.F.) \\ 2 National Interuniversity Consortium of Materials Science and Technology (INSTM), Via Giuseppe Giusti 9, \\ 50121 Florence, Italy \\ * Correspondence: lorenzo.bonetti@polimi.it; Tel.: +39-02-2399-4741
}

check for

updates

Citation: Bonetti, L.; De Nardo, L.; Farè, S. Chemically Crosslinked Methylcellulose Substrates for Cell Sheet Engineering. Gels 2021, 7, 141. https://doi.org/10.3390/gels7030141

Academic Editor: Esmaiel Jabbari

Received: 10 August 2021

Accepted: 10 September 2021

Published: 14 September 2021

Publisher's Note: MDPI stays neutral with regard to jurisdictional claims in published maps and institutional affiliations.

Copyright: (c) 2021 by the authors. Licensee MDPI, Basel, Switzerland. This article is an open access article distributed under the terms and conditions of the Creative Commons Attribution (CC BY) license (https:// creativecommons.org/licenses/by/ $4.0 /)$.

\begin{abstract}
Methylcellulose (MC) hydrogels have been successfully proposed in the field of cell sheet engineering (CSE), allowing cell detachment from their surface by lowering the temperature below their transition temperature $\left(\mathrm{T}_{\mathrm{t}}\right)$. Among the main limitations of pristine MC hydrogels, low physical stability and mechanical performances limit the breadth of their potential applications. In this study, a crosslinking strategy based on citric acid (CA) was used to prepare thermoresponsive MC hydrogels, with different degrees of crosslinking, to exploit their possible use as substrates in CSE. The investigated amounts of CA did not cause any cytotoxic effect while improving the mechanical performance of the hydrogels (+11-fold increase in E, compared to control MC). The possibility to obtain cell sheets (CSs) was then demonstrated using murine fibroblast cell line (L929 cells). Cells adhered on crosslinked MC hydrogels' surface in standard culture conditions and then were harvested at selected time points as single CSs. CS detachment was achieved simply by lowering the external temperature below the $\mathrm{T}_{\mathrm{t}}$ of MC. The detached CSs displayed adhesive and proliferative activity when transferred to new plastic culture surfaces, indicating a high potential for regenerative purposes.
\end{abstract}

Keywords: methylcellulose; citric acid; crosslinking; thermoresponsive hydrogels; cell sheet engineering (CSE)

\section{Introduction}

Cell sheet engineering (CSE) has emerged as a newsworthy approach in the tissue engineering and regenerative medicine fields [1-3]. CSE is a scaffold-free approach that allows overcoming some of the shortcomings associated with conventional scaffold-based approaches (e.g., biodegradation rate, host inflammatory response, stress shielding) [4,5]. Moreover, for regenerative purposes, CSE represents an advantage over the use of cell suspensions, in which a significant cell loss occurs after injection due to the low cell retention rates at the site of interest. Cell sheets (CSs) obtained via the CSE approach, retaining their deposited extracellular matrix (ECM), rich of adhesive proteins, have been successfully delivered to the host tissues and wound sites with minimal cell loss [6,7].

In this regard, thermoresponsive methylcellulose (MC) hydrogels are ideal substrates for the obtainment of CSs [8-11]. Specifically, the transition temperature $\left(T_{t}\right)$ can be conveniently set so that at $\mathrm{T}<\mathrm{T}_{\mathrm{t}} \mathrm{MC}$ is in a sol, hydrophilic state governed by hydrogen bonds between water molecules and the hydrophilic groups $(-\mathrm{OH})$ in the $\mathrm{MC}$ macromolecules. Conversely, at $\mathrm{T} \geq \mathrm{T}_{\mathrm{t}} \mathrm{MC}$ is in a gel, hydrophobic state, governed by hydrophobic interactions among the hydrophobic groups $\left(-\mathrm{CH}_{3}\right)$ of $\mathrm{MC}$ [12]. Cells cultured on MC hydrogels surface can be harvested as intact CSs simply by lowering the external temperature, avoiding the use of proteolytic enzymes, and thus preserving intact cell-cell junctions and the deposited ECM [12,13]. 
However, MC hydrogels display some major limitations [12]. According to previous research $[9,14-16]$, an $8 \% \mathrm{MC}$ hydrogel prepared in $50 \mathrm{mM} \mathrm{Na}_{2} \mathrm{SO}_{4}$ displays a $\mathrm{T}_{\mathrm{t}} \sim 37^{\circ} \mathrm{C}$, ideal for CSE. Nevertheless, it shows limited physical stability in the water environment ( $25 \%$ residual weight 7 days after immersion in $\mathrm{dH}_{2} \mathrm{O}$ ) and low mechanical performance $\left(\mathrm{G}^{\prime} \sim 10^{1}-10^{2} \mathrm{~Pa}\right.$ at $\left.37^{\circ} \mathrm{C}\right)$ [14]. In fact, when long-term cell cultures are expected, MC hydrogels' fast dissolution could impair their application. Furthermore, their low mechanical properties could fail to recapitulate the adequate environment required to guide the fate and functions (e.g., adhesion, spreading, differentiation) of the seeded cells [17] and the development of adequate CSs.

Chemical crosslinking, inducing the formation of covalent bonds among MC chains, can be regarded as an effective strategy to overcome the abovementioned limitations [12]. On this topic, different crosslinking methods have been proposed for MC crosslinking (e.g., photocrosslinking [18-20], $\gamma$ or electron beam irradiation [21,22], small molecule crosslinkers such as glutaraldehyde [21,23], divinyl sulfone [24], or citric acid [14,25]). However, the crosslinking process must be optimized in order not to alter the thermoresponsive behavior of the crosslinked MC gels. In fact, chemical crosslinking has been reported to cause shifts in the $T_{t}$ or even impair the responsive behavior of thermoresponsive hydrogels [12]. We previously reported the crosslinking of MC hydrogels by means of citric acid (CA) as an effective way to obtain hydrogels with superior physical and mechanical performances (i.e., reduced degradation in water environment and increased rheological parameters) by preserving thermoresponsiveness [14]. However, the possibility to obtain CSs from CA-crosslinked MC hydrogels has never been explored thus far.

In this work, we investigated the suitability of CA-crosslinked MC hydrogels in the CSE approach. Three different crosslinking degrees were analyzed and compared to MC control hydrogels. The obtained hydrogels were explored from a physical, mechanical, and biological point of view. First, swelling tests in water were carried out to assess the effectiveness of CA crosslinking in modulating the water uptake of MC gels. Additionally, a Flory-Rehner model was applied to the swelling data to calculate the main theoretical physical parameters describing the microstructure of the crosslinked gels. Then, tensile tests were carried out to assess Young's modulus (E) ranges of the MC gels. In vitro, indirect cytotoxicity was then carried out to exclude possible cytotoxic effects induced using CA as a crosslinker. Subsequently, L929 murine fibroblasts were seeded on the crosslinked MC samples, then confluent cell sheets were harvested from their surfaces simply by decreasing the external temperature from 37 to $4{ }^{\circ} \mathrm{C}$. Lastly, the adhesion and proliferation of the cells constituting the CSs were qualitatively evaluated in vitro to assess the regenerative potential of the obtained CSs.

\section{Results and Discussion}

\subsection{Hydrogels}

MC represents an optimal choice to produce thermoresponsive surfaces for CSE because of its low cost, simplicity of preparation, and easy tunability of its thermoresponsive behavior [8]. In particular, the accurate selection of MC concentration and the addition of salting-out ions are the key aspects to be considered to decrease the $\mathrm{T}_{\mathrm{t}}$ toward a range of interest for CSE applications (i.e., $\mathrm{T}_{\mathrm{t}}$ about $37^{\circ} \mathrm{C}$ ); indeed, a $2 \% \mathrm{MC}$ solution shows a typical $\mathrm{T}_{\mathrm{t}} \sim 60^{\circ} \mathrm{C}$ [12]. In this regard, $8 \% \mathrm{MC}$ and $50 \mathrm{mM} \mathrm{Na}_{2} \mathrm{SO}_{4}$ were selected based on previous studies $[9,16]$ to obtain a $\mathrm{T}_{\mathrm{t}}=37^{\circ} \mathrm{C}$.

Even if the transition temperature can easily be tuned by the addition of salting-out ions [16,26], the main limitations of MC hydrogels consist of their reduced water stability (i.e., fast dissolution) and low mechanical properties in physiological conditions. We previously reported a possible approach to MC crosslinking, based on citric acid (CA), for the obtainment of chemically crosslinked MC hydrogels with preserved thermoresponsive character [14]. In the present work, three optimized crosslinked MC hydrogel formulations (Table 1) were investigated for CSE purposes, comparing them to pristine MC hydrogels (i.e., used as control). In what follows, the differently crosslinked MC hydrogels will be 
referred to as MC-L, MC-M, MC-H, meaning low, medium, and high crosslinking degree, respectively. Table 1 also reports the content of citric acid (i.e., the crosslinking agent), the theoretical carboxyl content, and the weight fraction of CA taking part in ester bonds $\left(\mathrm{w}_{\text {ester, }},[14]\right)$ for each formulation here investigated. As it is possible to observe, the $\mathrm{w}_{\text {ester }}$ of MC-L samples is lower (0.6\%) than that of MC-M (51.3\%) and MC-H (77.6\%) samples, suggesting a low crosslinking degree of MC-L samples [14].

Table 1. MC hydrogel formulations: CA content, carboxyl content, and weight fraction of CA taking part in ester bonds.

\begin{tabular}{ccccc}
\hline Sample & $\begin{array}{c}\text { Crosslinking } \\
\text { Degree }\end{array}$ & $\begin{array}{c}{[\mathrm{CA}]} \\
\left(\mathbf{\%} \mathbf{w}_{\mathbf{C A}} / \mathbf{w}_{\mathbf{M C}}\right)\end{array}$ & $\begin{array}{c}-\mathrm{COOH} \\
(\mathbf{m m o l} / \mathbf{1 0 0} \mathbf{g})\end{array}$ & $\begin{array}{c}\mathbf{w}_{\text {ester }}{ }^{*} \\
\mathbf{( \% )}\end{array}$ \\
\hline MC & - & 0 & 0 & 0 \\
MC-L & Low & 1 & 15.6 & 0.6 \\
MC-M & Medium & 3 & 46.9 & 51.3 \\
MC-H & High & 5 & 78.1 & 77.6 \\
\hline${ }^{*}=$ Data taken from [14]. & & &
\end{tabular}

\subsection{Swelling Tests}

Figure 1A displays the swelling behavior of the crosslinked MC hydrogels within $48 \mathrm{~h}$ of incubation in distilled water at $37^{\circ} \mathrm{C}$. All the hydrogels showed a weight increase within the first $24 \mathrm{~h}$, due to water absorption. After $24 \mathrm{~h}$, a swelling plateau was reached for all the formulations, indicating that the swelling equilibrium was reached.

As it is possible to notice, the increase in the crosslinking degree of the samples causes a significant reduction $(p<0.05)$ in their swelling values. In particular, the swelling values at the swelling equilibrium were shown to be different $(p<0.05)$ when comparing the crosslinked MC hydrogels with MC control, with average swelling values ranging from $\sim 800 \%$ for MC-H to $3000 \%$ for MC-M. Conversely, MC-L did not show significant differences $(p>0.05)$ in terms of swelling at the equilibrium, compared to MC control. This suggests that low crosslinking slightly influenced the swelling behavior of the specimens [14]. In fact, an increase in the crosslinking degree causes an increase in crosslinking points, preventing the crosslinked MC network expansion in the water environment.
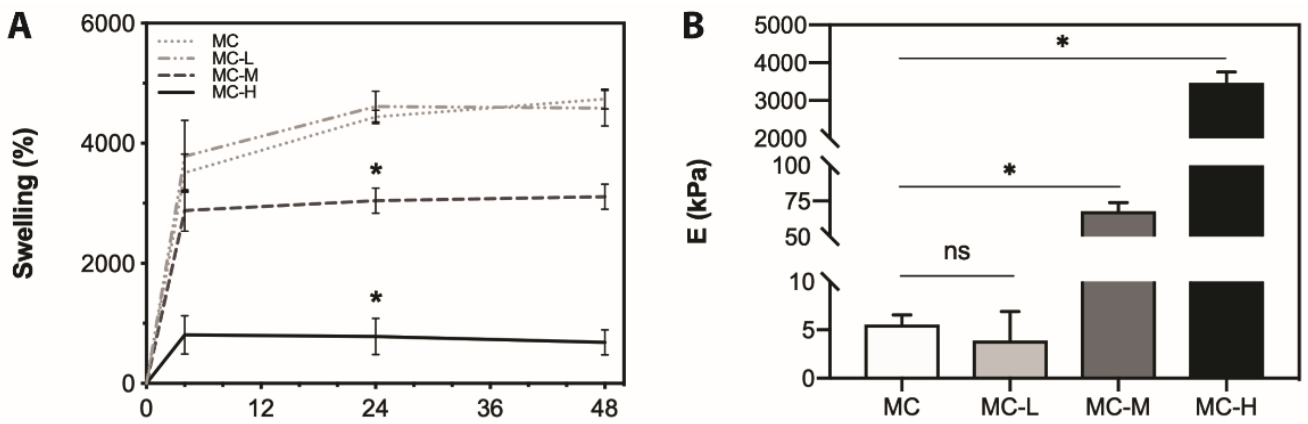

Figure 1. (A) Swelling behavior of the crosslinked MC specimens. The swelling equilibrium was identified at $\mathrm{t}=24 \mathrm{~h}$. ${ }^{*}=p<0.05$, compared to MC control; (B) Young's modulus (E) of CA-crosslinked MC hydrogels. ${ }^{*}=p<0.05$. Pristine MC hydrogel was used as control.

According to the Flory-Rehner model [14,27-29], it is possible to calculate the key parameters (Supplementary Material S1) defining the microstructure of crosslinked hydrogel networks, i.e., the average molecular weight between crosslinking points $\left(\overline{M_{C}}\right)$, the crosslinking density $\left(\rho_{C}\right)$, and the mesh size $(\xi)$, reported in Table 2 . Focusing on the crosslinking density (Table 2), it is possible to observe a $\sim 12$-fold increase in terms of $\rho_{C}$ from MC control $\left(0.20 \pm 0.01 \times 10^{4} \mathrm{~mol} \mathrm{~cm}^{-3}\right)$ to MC-H samples $\left(2.42 \pm 0.87 \times 10^{4} \mathrm{~mol} \mathrm{~cm}^{-3}\right)$. This indicates that the crosslinking degree of MC samples can be effectively tuned via a CA-based crosslinking procedure [14]. Similar results have also been obtained on methacry- 
lated MC hydrogels crosslinked with reduction-oxidation (redox) initiators, such as ammonium persulfate (APS)-ascorbic acid (AA) initiation system [29] or APS-N, $\mathrm{N} \mathrm{N}^{\prime}, \mathrm{N}^{\prime}$ tetramethylethylenediamine (TEMED) initiation system [30]. Interestingly, comparing the mesh size of these systems, $\xi$ values in the 40-80 nm range were observed for MC crosslinked with APS-AA redox system [29], while $\xi$ was in the $30-70 \mathrm{~nm}$ range in APSTEMED redox polymerization reactions [30]. The abovementioned ranges are in accordance with the $\xi$ values obtained in this work, ranging from 10 to $60 \mathrm{~nm}$. Slight differences in the $\xi$ values between this work and the abovementioned studies can be attributed to the different crosslinking agents used, the different $\mathrm{M}_{\mathrm{w}}$ of $\mathrm{MC}$ ( $88 \mathrm{kDa}$ vs. $14 \mathrm{kDa}$ ), and the different MC concentrations used.

Table 2. Theoretical physical parameters defining the microstructure of the crosslinked MC hydrogels. $\overline{M_{C}}=$ average molecular weight between crosslinking points, $\rho_{C}=$ crosslinking density, and $\xi=$ mesh size. ${ }^{*}, \#$, and $\dagger=$ significantly different $(p<0.05)$, compared to MC control.

\begin{tabular}{cccc}
\hline Sample & $\overline{\boldsymbol{M}_{\boldsymbol{C}}}\left(\mathbf{g ~ m o l}^{-1}\right)$ & $\rho_{C}(\mathbf{m o l ~ c m}$ \\
\hline MC & $1.36 \times 10^{4} \pm 5.33 \times 10^{2}$ & $0.20 \pm 0.01$ & $\xi(\mathbf{n m})$ \\
MC-L & $1.45 \times 10^{4} \pm 1.25 \times 10^{3}$ & $0.19 \pm 0.02$ & $59.98 \pm 1.64$ \\
MC-M & $7.72 \times 10^{3} \pm 7.70 \times 10^{2 *}$ & $0.36 \pm 0.04 \#$ & $62.53 \pm 3.77$ \\
MC-H & $1.28 \times 10^{3} \pm 5.77 \times 10^{2 *}$ & $2.42 \pm 0.87 \#$ & $11.29 \pm 3.51+$ \\
\hline
\end{tabular}

\subsection{Tensile Tests}

The mechanical properties of MC hydrogels were tested on hydrated (i.e., swelling equilibrium) samples to mimic the cell culture conditions. Figure 1B reports Young's moduli (E) calculated for each sample; it is possible to observe that the MC hydrogels stiffness was effectively modulated by increasing the crosslinking degree. As expected, highly crosslinked samples (MC-H) display the highest elastic modulus $(\mathrm{E}=3.47 \pm 0.29 \mathrm{MPa})$, while $\mathrm{MC}$ and MC-L samples display the lowest values $(\mathrm{E}=5.53 \pm 1.00 \mathrm{kPa}$ and $3.90 \pm 2.98 \mathrm{kPa}$, respectively). In particular, MC-L samples do not show any significant difference, compared to $\mathrm{MC}$ control, indicating poor effectiveness of CA crosslinking when a low CA concentration is used (Table 2). MC-M samples display $\mathrm{E}$ values midway between $\mathrm{MC}$ and $\mathrm{MC}-\mathrm{H}(\mathrm{E}=67.83 \pm 6.03 \mathrm{kPa})$, with a $\sim 11$-fold increase, compared to control (MC).

These outcomes are in accordance with previous rheological data on the same crosslinked MC samples, revealing an increase in the viscoelastic parameters $\left(G^{\prime}\right.$ and $\left.\eta^{*}\right)$ as a function of the crosslinking degree [14]. In this regard, the storage modulus ( $\left.\mathrm{G}^{\prime}\right)$ of $\mathrm{MC}-\mathrm{H}$ samples, at $\mathrm{T}=37^{\circ} \mathrm{C}$, was three orders of magnitude higher than that of MC. Similarly, Figure 1B displays a three order-of-magnitude increase in E values when comparing the highest crosslinking degree (MC-H) with MC control. The E values of the crosslinked MC hydrogels were obtained around their $T_{t}$, thus representing the values that these samples would display in cell culture environment $\left(\mathrm{T}=37^{\circ} \mathrm{C}\right.$, samples at the swelling equilibrium).

The tunability of the stiffness of a substrate for CSE can be relevant to design surfaces able to influence the overall response of the cultured cells. On this topic, it is widely accepted that mechanical (e.g., stiffness, viscosity) cues are essential parameters in surface design to modulate biological processes and even control cell fate (e.g., attachment, spreading, differentiation), similar to biochemical signals [31,32]. In particular, Young's modulus of biological tissues ranges from $100 \mathrm{~Pa}$ (e.g., neural tissue) to $10 \mathrm{GPa}$ (e.g., bone tissue) [33]. CA-crosslinked MC hydrogels would represent self-standing substrates capable to provide adequate mechanical cues to the seeded cells. Conversely, poly(N-isopropylacrlamide) (PNIPAAm), the reference material in the CSE field, needs to be grafted on a substrate with defined mechanical properties (e.g., E), to provide adequate cues to the seeded cells $[34,35]$.

The first step toward the obtainment of substrates for CSE capable to provide the predetermined mechanical properties while preserving their thermoresponsive behavior consists of verifying that CA-crosslinked MC substrates allow on-demand (i.e., temperaturetriggered) harvesting of CSs. 


\subsection{In Vitro Biological Tests}

2.4.1. Indirect Cytotoxicity

Cell viability around $100 \%$ was observed for each crosslinking condition (Figure 2), comparable to pristine MC, with no statistical differences $(p>0.05)$ among the samples.

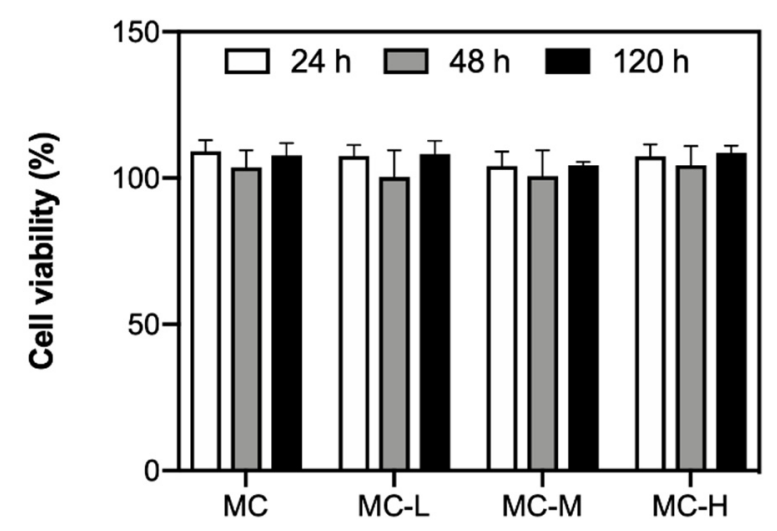

Figure 2. In vitro cytotoxicity test: viability of L929 cells kept in contact with 24,48 , and 120 h eluates of crosslinked MC hydrogel (pristine MC used as control).

These data suggest that the CA amounts used in our study (up to $5 \% \mathrm{w}_{\mathrm{CA}} / \mathrm{w}_{\mathrm{MC}}$ for MC-H samples) did not cause any cytotoxic effect on L929 cells. Our data are in accordance with previous studies in the literature exploiting CA as crosslinking agent [36-38]. In this regard, a concentration of CA up to $20 \%\left(\mathrm{w}_{\mathrm{CA}} / \mathrm{w}_{\text {polymer }}\right)$ has been demonstrated to be non-toxic yet effective to achieve crosslinking of different polymers (e.g., polyvinyl alcohol/starch [36], collagen [37]).

It should be noted that the efficiency of crosslinking is never $100 \%$ for all the crosslinked MC samples. In fact, according to our previous results on the same hydrogel formulations, the amount of $-\mathrm{COOH}$ of $\mathrm{CA}$ involved in ester bonds (i.e., $\mathrm{w}_{\text {ester, }}$, Table 1) ranged from $\sim 1 \%$ to $\sim 80 \%$, increasing the crosslinking degree (i.e., MC-L to MC-H samples) [14]. This means that residual (i.e., non-reacted) citric acid is present after the crosslinking procedure. However, in this study, the samples were not washed after the crosslinking procedure, since a washing step would have removed the $\mathrm{Na}_{2} \mathrm{SO}_{4}$ added during the preparation of MC hydrogels. Such removal would have caused a shift in the $T_{t}$ (due to the removal of salting-out anions [12]) of the MC hydrogels toward higher values, thus preventing their use for CSE purposes. Regardless, the amount of non-reacted CA in the investigated samples in this work was found to be non-cytotoxic (Figure 2), as demonstrated by cell viability values $>70 \%$ (i.e., the non-cytotoxicity threshold according to the standard ISO 10993-5:2009, "Biological evaluation of medical devices-Part 5: Tests for in vitro cytotoxicity"). Overall, these results suggest the possible use of crosslinked MC hydrogels as substrates for CSE.

\subsubsection{Cell Sheets Harvesting}

The scarce protein adsorption and limited cell adhesiveness of MC hydrogels make it necessary to implement strategies to open their use as platforms for CSE [8]: different approaches have been proposed to specifically address cell adhesion $[8,9,12,16,39-41]$. For instance, the immobilization of laminin-1, as a bio-adhesive ligand, has been employed on in situ gelling MC hydrogels for neural tissue engineering [39]. Another possible approach to improve cell adhesion consists of blending $\mathrm{MC}$ with other polymers (e.g., agarose [40], collagen [41]). In the field of CSE, the surface of each MC hydrogel is usually modified with collagen absorbed prior to cell seeding $[8,9,16]$. In this work, rat tail type I collagen was adsorbed on the surface of MC hydrogels as a preliminary stage to increase cell adhesion. Figure 3A (right) displays the poorly adhesivity of MC surface without collagen, which leads to the formation of cell aggregates. Conversely, rat tail type I collagen 
absorption resulted in L929 cell adhesion and spreading on the surface of the MC hydrogels Figure $3 \mathrm{~A}$ (left). These observations are in accordance with previous studies in the literature on the role of type I collagen absorption on MC surface in effectively promoting cell adhesion $[8,42]$.

L929 cells on collagen-treated MC hydrogels were cultured for 24 and $120 \mathrm{~h}$. Under culture conditions (i.e., $\mathrm{T}=37^{\circ} \mathrm{C}$ ), thermoresponsive $\mathrm{MC}$ surfaces are relatively hydrophobic, allowing cells to attach and proliferate. CS detachment was achieved by lowering the external temperature to $4{ }^{\circ} \mathrm{C}\left(\mathrm{T}<\mathrm{T}_{\mathrm{t}}\right)$ for $20 \mathrm{~min}$. In these conditions, $\mathrm{MC}$ structure changes to hydrophilic, forming a hydration layer between the cells and the MC surface. Thus, cells spontaneously detach as an intact CS (Figure 3B), without the need for any treatment (e.g., trypsin-based treatment) [9]. CSs with a diameter of $15 \mathrm{~mm}$ (Figure 3C) were harvested from MC, MC-L, and MC-M hydrogels. Conversely, the harvesting was not feasible from the surface of MC hydrogels with the highest crosslinking degree (MC-H). This supports our previous results, which displayed how excessive crosslinking (i.e., MC-H) leads to the loss of the hydrogel thermoresponsiveness [14]. This phenomenon has been demonstrated to be caused by the formation of a dense crosslinking network, which limits MC chains mobility, thus constraining the formation of weak interactions (i.e., H-bonds among water and $\mathrm{MC}$ chains, and $\mathrm{CH}_{3}-\mathrm{CH}_{3}$ bonds among $\mathrm{MC}$ chains) responsible for the thermoresponsive behavior of MC hydrogels [14].

Due to the impossibility to detach CSs from MC-H substrates, for the subsequent characterization only MC, MC-L, and MC-M formulations were considered.

A

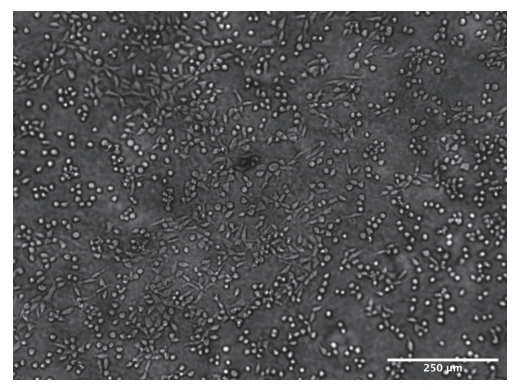

MC + collagen

B

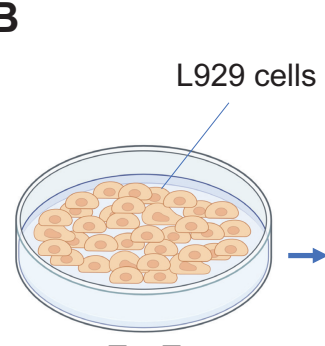

$\mathrm{T} \geq \mathrm{T}_{\mathrm{t}}$

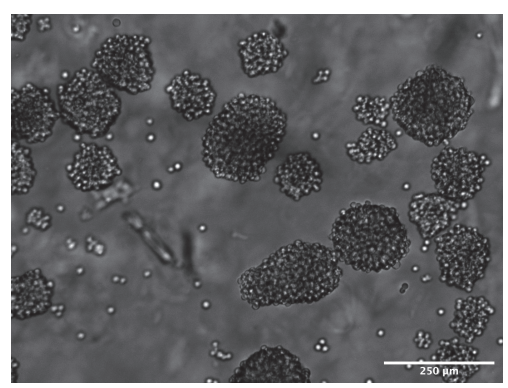

MC

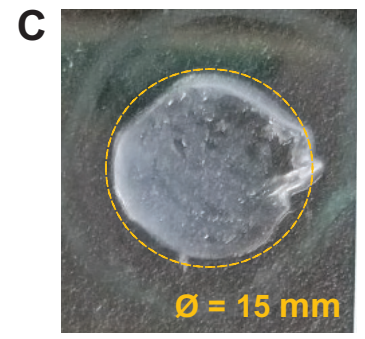

Figure 3. (A) Effect of rat tail type I collagen coating on cell adhesiveness of MC $24 \mathrm{~h}$ after seeding. Pristine MC, without collagen absorption (right) does not support the adhesion of L929 cells, which form aggregates on the hydrogel surface. Conversely, L929 cells seeded on collagen-coated MC adhere and spread on the MC surface (left). Scale bar $=250 \mu \mathrm{m}$; (B) scheme of $\mathrm{CS}$ harvesting: at $37^{\circ} \mathrm{C}$ (i.e., $\mathrm{T} \geq \mathrm{T}_{\mathrm{t}}$ ), L929 cells adhere and proliferate on the MC surface, due to its moderately hydrophobic nature. At $\mathrm{T}<37^{\circ} \mathrm{C}, \mathrm{MC}$ changes to hydrophilic, allowing the spontaneous detachment of an intact CS; (C) representative image of an intact L929 CS detached from the surface of a thermoresponsive MC hydrogel. 


\subsubsection{Cell Sheets Characterization}

L929 metabolic activity was investigated 24 and $48 \mathrm{~h}$ after cell seeding on the MC hydrogels under study (Figure 4A). The resazurin assay revealed cell viability around $100 \%$ for both MC-L and MC-M samples when compared to control (MC), indicating evident proliferation and viability of cells in contact with the MC hydrogels. A significantly lower $(p<0.05)$ cell viability was detected for MC-L samples $24 \mathrm{~h}$ after seeding, probably due to a delayed cell proliferation on this substrate, compared to MC control. However, at $\mathrm{t}=48 \mathrm{~h}$, cell viability was found comparable to the one of MC control.

A

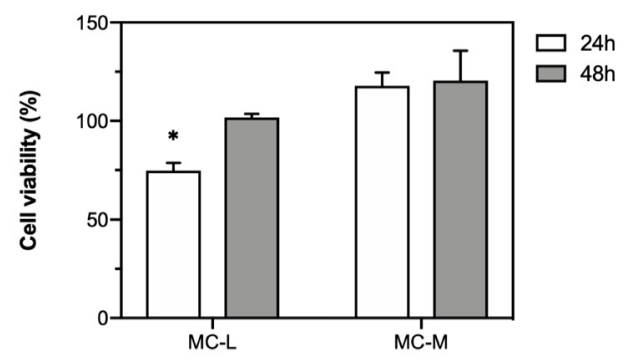

C

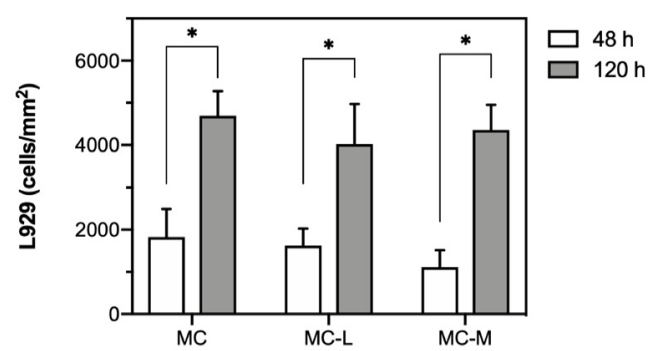

B
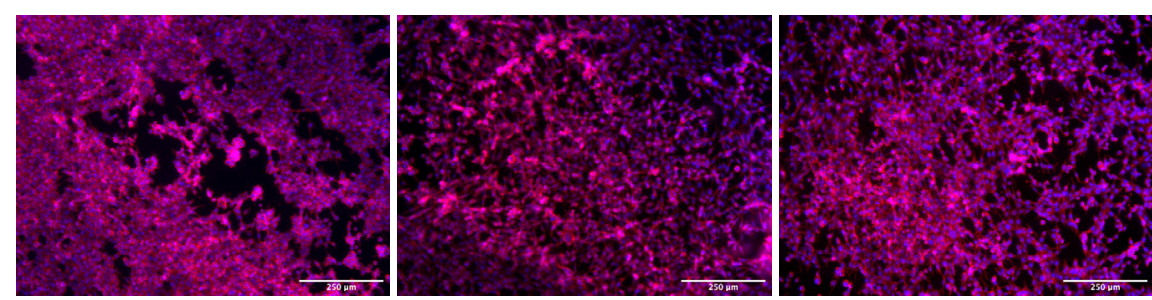

$48 \mathrm{~h}$

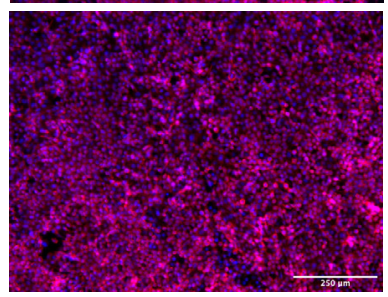

MC

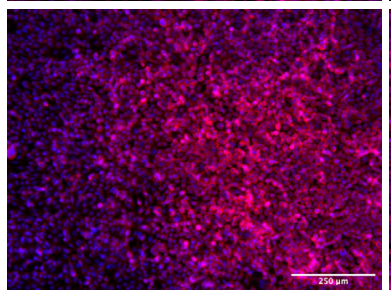

MC-L

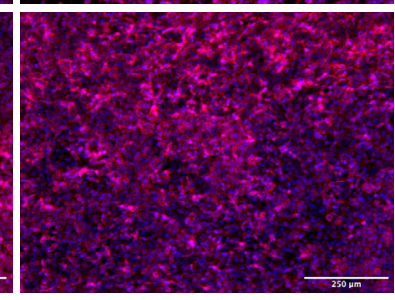

MC-M

Figure 4. (A) L929 metabolic activity on MC hydrogels after culture for 24 and $48 \mathrm{~h}$. MC was used as control. ${ }^{*}=p<0.05$ compared to MC control; (B) fluorescence micrographs of L929 CSs detached from MC, MC-L, and MC-H hydrogels, 48 and $120 \mathrm{~h}$ after seeding. Scale bar $=250 \mu \mathrm{m}$; (C) cell density (cells $/ \mathrm{mm}^{2}$ ) calculated from image analysis, for MC, MC-L, and MC-H hydrogels, 48 and $120 \mathrm{~h}$ after seeding. ${ }^{*}=p<0.05$.

Fluorescence micrographs of the CSs after 48 and $120 \mathrm{~h}$ of culture (Figure 4B) qualitatively revealed the presence of widespread red areas, indicating the actin filaments in the cytoskeleton, also contributing to cell-cell junction in the obtained CSs [9]. The produced CSs appeared compact, indicating a good cell cohesiveness reached in the culture time length. Moreover, it was possible to qualitatively observe an increase in cell density between 48 and $120 \mathrm{~h}$ cultured CSs.

The cell density was quantitatively assessed by means of image analysis, which confirmed the aforesaid qualitative observations. Specifically, a significant $(p<0.05)$ increase in cell density was observed for all the MC substrates, between 48 and $120 \mathrm{~h}$ of cell culture (Figure $4 \mathrm{C}$ ). The theoretical cell density for $48 \mathrm{~h}$ cultured CSs was calculated by considering the cell seeding density $\left(1.5 \times 10^{5}\right.$ cells/well $)$ and L929 cells division time ( $14 \mathrm{~h},[43])$. The theoretical cell density after $48 \mathrm{~h}$ is $\sim 9000$ cells $/ \mathrm{mm}^{2}$ (Supplementary Material S3), higher than the measured one $\sim 2000$ cells $/ \mathrm{mm}^{2}$ (Figure 4C). This difference can be explained by the fact that L929 cells were already close to confluency due to the high seeding density (Supplementary Material S4) Additionally, it is possible to observe 
(Figure 4C) that, despite the extended culture time, only a twofold increase in the cell density values was achieved for $120 \mathrm{~h}$ cultured CSs compared to $48 \mathrm{~h}$ cultured CSs. This small increase in cell density values for all MC samples further confirmed the fact that the L929 cells have reached confluency between 48 and $120 \mathrm{~h}$ [13]. For each cell culture time (48 or $120 \mathrm{~h}$ ), no significant differences in terms of cell density were observed among the CSs obtained from differently crosslinked samples (MC, MC-L, and MC-M).

For each crosslinked MC substrate, two CSs were transferred to a new 12-well plate (12-MW) to qualitatively assess the CSs adhesive and proliferation activities on a new substrate. The CSs started to adhere to the new substrates shortly after their transfer ( 20 min). Adhesion was confirmed, as the CSs remained on the bottom of the wells after the addition of further DMEM (i.e., $250 \mu \mathrm{L} /$ well, used to extend the CSs culture time up to $72 \mathrm{~h}$ ). Interestingly, $72 \mathrm{~h}$ after their transfer, CSs qualitatively preserved their closely interconnected structure, indicating that cell-cell junctions have not been destroyed after CSs harvesting from the MC hydrogel surfaces. Moreover, optical microscopy observation $72 \mathrm{~h}$ after CSs transfer (Figure 5) revealed that the L929 cells started to migrate from the CS to the bottom of the 12-MW wells. No qualitative differences in cell adhesion and proliferation were observed among the CSs obtained from the crosslinked MC substrates and MC control.
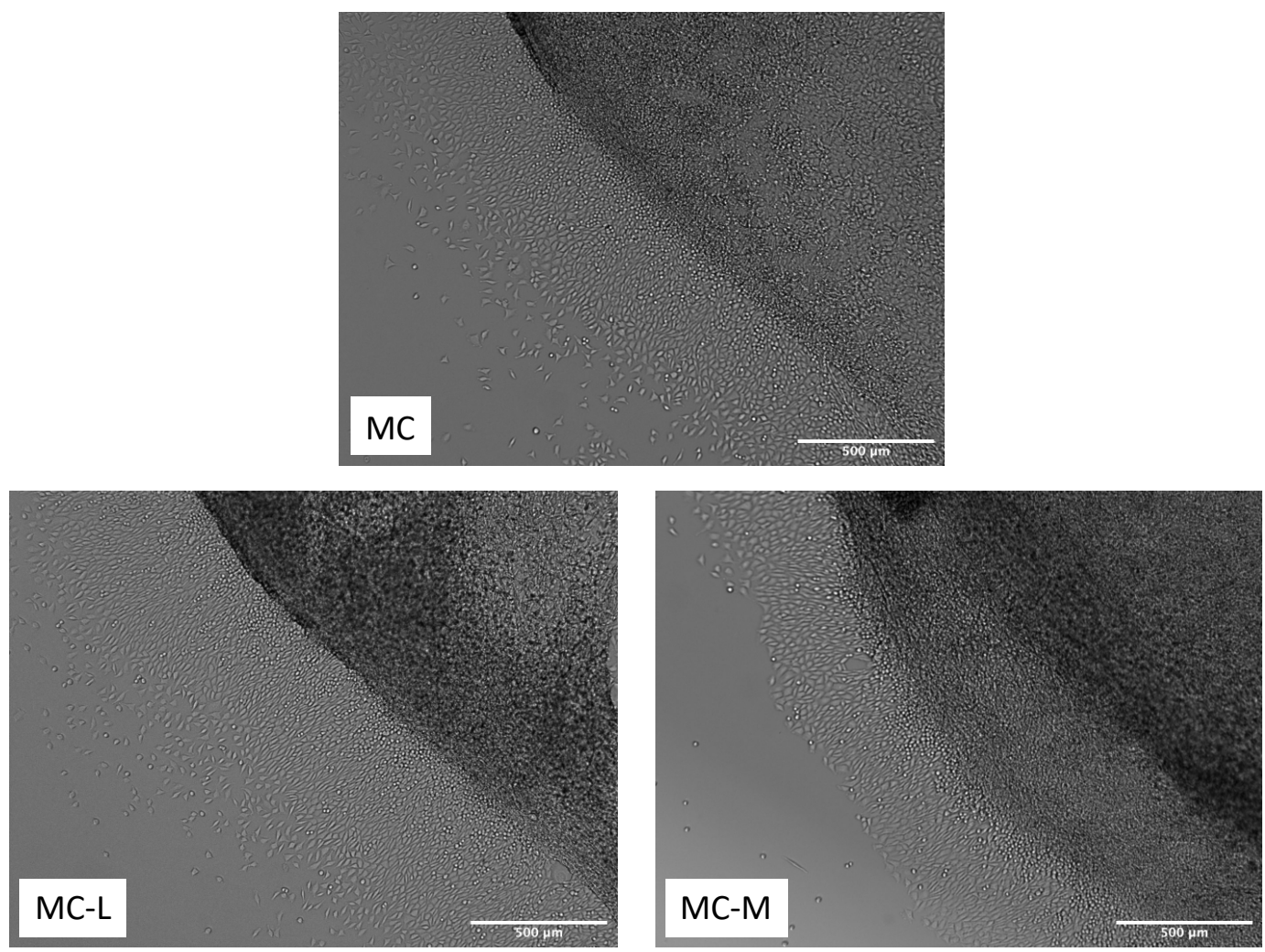

Figure 5. CSs cultured for $72 \mathrm{~h}$ on a new substrate (12-MW). Cell migration and proliferation from each CS (upper right side) to the well bottom (lower left side) can be observed in the shading degree of each image. Scale bar $=500 \mu \mathrm{m}$.

Taken together, these observations disclose the potential of CSs obtained from crosslinked MC thermoresponsive hydrogels for tissue regeneration [9]. The obtained CSs, avoiding the use of scaffolding materials as cell carriers, could prevent materials-related complications (e.g., host inflammatory response). Moreover, by preserving intact cell-cell junctions and their deposited ECM, they could be implanted in the host tissues without the need for any mediators (e.g., fibrin glue or sutures) $[44,45]$. Complex tissues could also be regenerated by multiple transplants of CSs (even of different cell types) in the host tissues or by transplanting in vitro-layered CS [46]. 
The obtained results show that CSs detached from the surface of crosslinked MC hydrogels displayed no qualitative and quantitative differences, compared with control MC samples. It is well documented how the growth of L929 cells is insensitive to the stiffness of the culture surface, supporting that the capability to sense or respond to mechanical cues may be impaired in some cell types, e.g., immortalized or cancer cells [47-49]. On this topic, Mih et al. revealed the insensitiveness of L929 cells to substrates with stiffnesses in the 0.1-100 kPa range [49], comparable to the one investigated in the present study. Moreover, even substrates with higher $\mathrm{E}$ ranges (i.e., in the order of $\mathrm{MPa}$ ) have been reported not to influence the spreading and the shape of L929 cells seeded on them [50]. Since the present study was intended as a bench test for crosslinked MC substrates to evaluate their responsive behavior in the field of CSE, the obtained outcomes should not be considered unfavorable. On the contrary, these outcomes identify CA-crosslinked MC hydrogels as noteworthy substrates for CSE applications. In fact, in addition to the possibility to harvest CSs, they offer unique advantages, compared to pristine MC hydrogels. First, their increased water stability would allow their use for prolonged cell culture times, at the state-of-the-art limited by the fast dissolution of pristine MC hydrogels in the water environment $[9,14]$. Moreover, the tuning of the crosslinking parameters allowed obtaining MC substrates with E values in the 5-75 $\mathrm{kPa}$ range (MC to $\mathrm{MC}-\mathrm{M}$ ) and with preserved thermoresponsive character. Such substrates can be regarded as promising self-standing platforms with tunable mechanical performances, useful, for instance, to guide the fate of selected cell types (e.g., mesenchymal stem cells) and obtain mature (i.e., differentiated) CSs [31]. Nevertheless, further tuning of the crosslinking process, exploring crosslinking conditions midway between MC-M and MC-H, could provide thermoresponsive substrates with superior performances, compared to MC-M hydrogels (representing, in this work, the upper limit in terms of preserved thermoresponsive character).

\section{Conclusions}

In this work, we demonstrated the feasibility of obtaining CSs from CA-crosslinked MC substrates. CSs were successfully detached from optimized crosslinked MC hydrogels, despite excessive crosslinking (i.e., MC-H) leading to the loss of the thermoresponsive behavior of MC, thus preventing CSs detachment. The CSs obtained from crosslinked $\mathrm{MC}$ hydrogels displayed no differences in terms of viability, adhesive, and proliferative activities, compared to the CSs obtained from MC control.

Overall, these results open the floodgates to the obtainment of stable (e.g., to aqueous or cell culture environment) MC hydrogels, suitable for prolonged cell culture times. Moreover, CA-crosslinked MC hydrogels could represent self-standing and mechanically tunable substrates for CSE, which lend themselves to guiding and regulating the fate of the seeded cells (e.g., stem cells).

\section{Materials and Methods}

Unless stated, all chemicals were purchased from Sigma-Aldrich (Milan, (MI), Italy) and used as received without further purification.

\subsection{Hydrogels Preparation}

Methylcellulose (MC) hydrogels were prepared according to a previously reported protocol [14]. Briefly, an 8\% w/v MC (M0512) suspension was prepared by dispersing MC powder in a $0.05 \mathrm{M} \mathrm{Na}_{2} \mathrm{SO}_{4}$ deionized water solution, at $55^{\circ} \mathrm{C}$. Citric acid (CA) (SigmaAldrich, Milan, Italy), the crosslinking agent, was added in different concentrations $(1,3$, or $\left.5 \% \mathrm{w}_{\mathrm{CA}} / \mathrm{w}_{\mathrm{MC}}\right)$ to the solution. The obtained suspensions were dispensed $\left(\mathrm{T}=4{ }^{\circ} \mathrm{C}\right.$, $\mathrm{t}=24 \mathrm{~h}$ ) into Petri dishes (Euroclone, Pero, Italy), then oven-dried $\left(\mathrm{T}=50^{\circ} \mathrm{C}, \mathrm{t}=24 \mathrm{~h}\right.$ ) to obtain MC films. Lastly, MC crosslinking was achieved by thermal treatment, varying the crosslinking time and temperature according to Table 3. Non-crosslinked MC samples were used as controls. 
Table 3. MC samples prepared and characterized in this work. MC = non-crosslinked sample. MC-L = low crosslinking; $\mathrm{MC}-\mathrm{M}=$ medium crosslinking; $\mathrm{MC}-\mathrm{H}=$ high crosslinking.

\begin{tabular}{cccc}
\hline Sample & $\begin{array}{c}{[\mathrm{CA}]} \\
\left(\mathbf{\%} \mathbf{w}_{\mathbf{C A}} / \mathbf{w}_{\mathbf{M C}}\right)\end{array}$ & Temperature $\left({ }^{\circ} \mathbf{C}\right)$ & $\begin{array}{c}\text { Time } \\
(\mathbf{m i n})\end{array}$ \\
\hline MC & - & - & - \\
\hline MC-L & 1 & 165 & 1 \\
\hline MC-M & 3 & 177.5 & 8 \\
\hline MC-H & 5 & 190 & 15 \\
\hline
\end{tabular}

\subsection{Swelling Tests}

The swelling properties of MC hydrogels were investigated by placing dry MC samples ( $n=3$ for each formulation) into cell strainers (mesh size $=40 \mu \mathrm{m}$, Corning, New York, NY, USA) and immersing them in distilled water $\left(\mathrm{dH}_{2} \mathrm{O}\right)$ at $37^{\circ} \mathrm{C}$. At different time points (i.e., $4,24,48 \mathrm{~h}$ ), the strainers were withdrawn from the water, gently blotted on tissue paper to remove excess water, then weighted. The swelling ratio (SW) was calculated according to the following equation (Equation (1)):

$$
\operatorname{SW}(\%)=\frac{w_{t}-w_{0}}{w_{0}} \times 100
$$

where $w_{t}$ and $w_{0}$ represent the weight at time $t$ (i.e., wet weight), and the weight at time 0 (i.e., dry weight) of an MC sample, respectively. The swelling equilibrium was considered when no significant differences in terms of SW were detected among two subsequent time points.

\subsection{Mechanical Tensile Tests}

MC samples ( $n=3$ for each formulation) at the swelling equilibrium (i.e., $\mathrm{t}=24 \mathrm{~h}$ for all samples, $\mathrm{T}=37^{\circ} \mathrm{C}$, in $\mathrm{dH}_{2} \mathrm{O}$ [14]) were tested by Dynamic Mechanical Analyzer (DMA Q800, TA Instruments, New Castle, DE, USA), equipped with tension clamps. A preload of $0.001 \mathrm{~N}$ was applied, followed by a strain-controlled ramp at a $0.3 \mathrm{~min}^{-1}$ rate. Young's modulus (E) was calculated from the stress-strain curves as the slope in the $0-5 \%$ strain range $\left(R^{2}>0.95\right)$.

\subsection{In Vitro Biological Tests}

MC dry films were UV sterilized (30 min/side) prior to in vitro testing. Samples were then immersed in sterile distilled water, at $37^{\circ} \mathrm{C}$, for $24 \mathrm{~h}$ to reach the swelling equilibrium.

\subsubsection{Indirect Cytotoxicity}

In vitro indirect cytotoxicity tests were performed to assess the possible release of toxic compounds from the crosslinked MC hydrogels. Complete Dulbecco's modified Eagle medium (DMEM) with the addition of $1 \mathrm{mM}$ sodium pyruvate, $10 \mathrm{mM}$ HEPES buffer, $100 \mathrm{U} \mathrm{mL}^{-1}$ penicillin, $0.1 \mathrm{mg} \mathrm{mL}^{-1}$ streptomycin, $2 \mathrm{mM}$ glutamine, and $10 \%(v / v) \mathrm{fe}-$ tal bovine serum was used as an extraction medium. Circular MC hydrogel samples $(\Phi=15 \mathrm{~mm})$ were obtained by a manual punch. Each specimen $(n=3$ for each crosslinking condition and each time point) was immersed in the extraction medium $\left(3 \mathrm{~cm}^{2} 1 \mathrm{~mL}^{-1}\right.$ extraction ratio, according to the ISO 10993-12 standard for samples with thickness in the $0.5<\mathrm{t}<1 \mathrm{~mm}$ range) and then incubated at $37^{\circ} \mathrm{C}$ for $(24,48$, and 120$) \mathrm{h}$. At each time point, eluates were harvested; aged $(24,48$, and $120 \mathrm{~h})$ DMEM culture medium, without MC, was used as control (CTRL).

L929 murine fibroblasts ( $n$ 85011425, ECACC, Public Health England, Salisbury, UK) were seeded in a 96-well plate (cell density $=1 \times 10^{4}$ cells/well) and cultured with $100 \mu \mathrm{L}$ of complete DMEM for $24 \mathrm{~h}$. Then, DMEM was replaced with eluates or control culture media $(100 \mu \mathrm{L})$, and cells were incubated for a further $24 \mathrm{~h}$ in standard culture conditions. 
Cell metabolic activity was assessed by resazurin assay [16]. Fluorescence was measured with a Synergy H1 spectrophotometer (BioTek, Santa Clara, CA, USA; $\lambda_{\mathrm{ex}}=540 \mathrm{~nm}$, $\lambda_{\mathrm{em}}=595 \mathrm{~nm}$ ) for cells cultured in the eluates ( $\left.\mathrm{RFU}_{\text {sample }}\right)$ and in the aged culture medium $\left(\mathrm{RFU}_{\mathrm{CRTL}}\right)$, after background fluorescence subtraction of the resazurin solution incubated without cells $\left(\mathrm{RFU}_{\text {resazurin }}\right)$. For each well, cell viability was calculated according to the following equation (Equation (2)):

$$
\text { Viability }(\%)=\left[\frac{R F U_{\text {sample }}-R F U_{\text {resazurin }}}{R F U_{\text {CTRL }}-R F U_{\text {resazurin }}}\right] \times 100
$$

\subsubsection{Cell Culture}

For each crosslinking condition, circular hydrogel specimens $(\Phi=20 \mathrm{~mm})$ were obtained by a manual punch. The hydrogel specimens ( $n=3$ for each crosslinking condition) were positioned on the bottom of the tissue-culture multiwell plate (12 wells, 12-MW, Euroclone, Pero, (MI), Italy), and kept in position by means of polydimethylsiloxane (PDMS, Elastosil RT 601, Wacker, Munich, Germany) rings $\left(\Phi_{\mathrm{EXT}}=22 \mathrm{~mm}, \Phi_{\mathrm{INT}}=15 \mathrm{~mm}\right.$, Supplementary Material S2). Prior to cell seeding, $200 \mu \mathrm{L}$ of type I collagen extracted from rat tail $\left(4 \mathrm{mg} \mathrm{mL}^{-1}\right)$ were adsorbed on the surface of each hydrogel specimen to enhance cell adhesion [9]. L929 cells were seeded (1.5 $\times 10^{5}$ cells/well in $100 \mu \mathrm{L}$ DMEM [9]) on each specimen and cultured in standard culture conditions for 48 or $120 \mathrm{~h}$.

\section{CSs Harvesting}

After 24 or $120 \mathrm{~h}$ of culture, the plates were removed from the incubator and placed at $4{ }^{\circ} \mathrm{C}$ for $20 \mathrm{~min}$. This procedure allowed the produced CSs to spontaneously detach from the MC hydrogel surface (Figure 3B,C). CSs were collected by adding PBS at $\mathrm{T}=4{ }^{\circ} \mathrm{C}$ into each well and sucking them up with a $50 \mathrm{~mL}$ pipette. The obtained CSs were then moved onto electrostatic glass slides or into a new 12-MW well for immunofluorescence staining and adhesion/proliferation tests, respectively.

\section{Resazurin Assay}

L929 metabolic activity was investigated by performing tests on cells cultured on MC specimen ( $n=3$ for each crosslinking condition), 24 and $48 \mathrm{~h}$ after seeding, by means of the resazurin assay, as previously described. Previous in vitro cytocompatibility tests on non-crosslinked hydrogel formulation (i.e., $\mathrm{MC}$ ) revealed good proliferation and viability of cells in contact with MC hydrogels [9]. Thus, cells cultured on MC hydrogels were used as control. For each well, cell viability was calculated according to the following equation (Equation (3)):

$$
\text { Viability }(\%)=\left[\frac{R F U_{M C-X}-R F U_{\text {resazurin }}}{R F U_{M C}-R F U_{\text {resazurin }}}\right] \times 100
$$

where MC-X = MC-L, MC-M, or MC-H.

Immunofluorescence Staining

The detached CSs ( $n=1$ for each crosslinking condition) were transferred to electrostatic slides, rinsed with PBS solution, then fixed with a $4 \%(v / v)$ paraformaldehyde solution in PBS for $20 \mathrm{~min}$ at room temperature. After rinsing with PBS solution, the CSs were permeabilized with $0.2 \%(v / v)$ Triton X-100 in PBS for $20 \mathrm{~min}$ at room temperature. Each CS was then stained (60 min at room temperature) with $100 \mu \mathrm{L}$ of a $0.2 \%(v / v)$ Triton X-100 solution in PBS containing phalloidin (P1951, $4 \mu \mathrm{g} / \mathrm{mL}$ ) to stain actin filaments, and Hoechst (Hoechst 33342, ThermoFisher Scientific, Waltham, MA, USA, $1 \mu \mathrm{g} / \mathrm{mL}$ ) to stain the nuclei. After rinsing with PBS, 2-3 drops of Fluoromount (F4680) were applied on each CS, and a coverslip was gently applied. The specimens were observed with a fluorescent microscope (Zeiss Axioplan, Oberkochen, Germany). Cell density (cells $\mathrm{mm}^{-2}$ ) was calculated by image analysis (ImageJ, v. 1.53, NIH, National Institutes of Health, Bethesda, MD, 
USA), counting the average number of nuclei in the acquired images ( $n=5$ for each CS) and dividing it by the area of the images $\left(0.148 \mathrm{~mm}^{2}\right.$, Supplementary Material S3).

Adhesion and Proliferation on a New Substrate

CSs detached from MC hydrogels ( $n=2$ for each crosslinking condition) were transferred to a new 12-MW to qualitatively assess CSs adhesion and proliferation on a new substrate. A total of $50 \mu \mathrm{L}$ of DMEM was added to each CS to avoid dehydration. After $20 \mathrm{~min}$, an additional $250 \mu \mathrm{L}$ of DMEM was added to each well, and CSs were cultured in standard culture conditions. After $72 \mathrm{~h}$ of culture, CSs were observed by optical microscope (Zeiss Axioplan) to evaluate the potential L929 cells migration outside of each CS.

\subsection{Statistical Data Analysis}

All tests were carried out in triplicate $(n=3)$. Data are reported as mean \pm standard deviation (SD). Statistical analysis (GraphPad Prism v 8.0, San Diego, CA, USA) was performed using single $t$-tests or one-way ANOVA tests, with significance level $p=0.05$.

Supplementary Materials: The following are available online at https:/ /www.mdpi.com/article/10 .3390/gels7030141/s1, Supplementary Material S1: Flory-Rehner model, Supplementary Material S2: Plate scheme for CSs production, Supplementary Material S3: Cell density, Supplementary Material S4: Confluency.

Author Contributions: Conceptualization, methodology, formal analysis, investigation, writingoriginal draft, writing — review and editing, visualization, L.B.; conceptualization, resources, writingreview and editing, supervision, L.D.N.; conceptualization, resources, writing-review and editing, supervision, S.F. All authors have read and agreed to the published version of the manuscript.

Funding: This research received no external funding.

Institutional Review Board Statement: Not applicable.

Informed Consent Statement: Not applicable.

Acknowledgments: The authors acknowledge Paolo Tarsini for his support with immunofluorescence staining.

Conflicts of Interest: The authors declare no conflict of interest.

\section{References}

1. Owaki, T.; Shimizu, T.; Yamato, M.; Okano, T. Cell sheet engineering for regenerative medicine: Current challenges and strategies. Biotechnol. J. 2014, 9, 904-914. [CrossRef]

2. Kobayashi, J.; Kikuchi, A.; Aoyagi, T.; Okano, T. Cell sheet tissue engineering: Cell sheet preparation, harvesting/manipulation, and transplantation. J. Biomed. Mater. Res. Part A 2019, 107, 955-967. [CrossRef] [PubMed]

3. Devireddy, R.V. Cell sheets for tissue engineering applications. In Cell Engineering and Regeneration; Springer International Publishing: Cham, Switzerland, 2019; pp. 1-20.

4. Moschouris, K.; Firoozi, N.; Kang, Y. The application of cell sheet engineering in the vascularization of tissue regeneration. Regen. Med. 2016, 11, 559-570. [CrossRef]

5. Akiyama, Y. Design of temperature-responsive cell culture surfaces for cell sheet engineering. Cyborg Bionic Syst. 2021, 2021, 1-15.

6. Yang, J.; Yamato, M.; Nishida, K.; Ohki, T.; Kanzaki, M.; Sekine, H.; Shimizu, T.; Okano, T. Cell delivery in regenerative medicine: The cell sheet engineering approach. J. Control. Release 2006, 116, 193-203. [CrossRef] [PubMed]

7. Li, M.; Ma, J.; Gao, Y.; Yang, L. Cell sheet technology: A promising strategy in regenerative medicine. Cytotherapy 2019, 21, 3-16. [CrossRef] [PubMed]

8. Thirumala, S.; Gimble, J.; Devireddy, R. Methylcellulose based thermally reversible hydrogel system for tissue engineering applications. Cells 2013, 2, 460-475. [CrossRef]

9. Cochis, A.; Bonetti, L.; Sorrentino, R.; Contessi Negrini, N.; Grassi, F.; Leigheb, M.; Rimondini, L.; Farè, S. 3D printing of thermo-responsive methylcellulose hydrogels for cell-sheet engineering. Materials 2018, 11, 579. [CrossRef]

10. Taylor, M.; Tomlins, P.; Sahota, T. Thermoresponsive gels. Gels 2017, 3, 4. [CrossRef]

11. Mokhtarinia, K.; Masaeli, E. Transiently thermally responsive surfaces: Concepts for cell sheet engineering. Eur. Polym. J. 2020, 141, 110076. [CrossRef]

12. Bonetti, L.; De Nardo, L.; Farè, S. Thermo-responsive methylcellulose hydrogels: From design to applications as smart biomaterials. Tissue Eng. Part B Rev. 2020. [CrossRef] 
13. Chen, C.-H.; Tsai, C.-C.; Chen, W.; Mi, F.-L.; Liang, H.-F.; Chen, S.-C.; Sung, H.-W. Novel living cell sheet harvest system composed of thermoreversible methylcellulose hydrogels. Biomacromolecules 2006, 7, 736-743. [CrossRef]

14. Bonetti, L.; De Nardo, L.; Variola, F.; Fare', S. Evaluation of the subtle trade-off between physical stability and thermoresponsiveness in crosslinked methylcellulose hydrogels. Soft Matter 2020, 16, 5577-5587. [CrossRef] [PubMed]

15. Bonetti, L.; De Nardo, L.; Variola, F.; Farè, S. In-situ Raman spectroscopy: An effective technique for the quantification of LCST transition of methylcellulose hydrogels. Mater. Lett. 2020, 274, 128011. [CrossRef]

16. Altomare, L.; Cochis, A.; Carletta, A.; Rimondini, L.; Farè, S. Thermo-responsive methylcellulose hydrogels as temporary substrate for cell sheet biofabrication. J. Mater. Sci. Mater. Med. 2016, 27, 95. [CrossRef] [PubMed]

17. Bloom, A.B.; Zaman, M.H. Influence of the microenvironment on cell fate determination and migration. Physiol. Genomics 2014, 46, 309-314. [CrossRef]

18. Morozova, S.; Coughlin, M.L.; Early, J.T.; Ertem, S.P.; Reineke, T.M.; Bates, F.S.; Lodge, T.P. Properties of chemically cross-linked methylcellulose gels. Macromolecules 2019, 52, 7740-7748. [CrossRef]

19. Stalling, S.S.; Akintoye, S.O.; Nicoll, S.B. Development of photocrosslinked methylcellulose hydrogels for soft tissue reconstruction. Acta Biomater. 2009, 5, 1911-1918. [CrossRef]

20. Shin, J.Y.; Yeo, Y.H.; Jeong, J.E.; Park, S.A.; Park, W.H. Dual-crosslinked methylcellulose hydrogels for 3D bioprinting applications. Carbohydr. Polym. 2020, 238, 116192. [CrossRef]

21. Rimdusit, S.; Somsaeng, K.; Kewsuwan, P.; Jubsilp, C.; Tiptipakorn, S. Comparison of gamma radiation crosslinking and chemical crosslinking on properties of methylcellulose hydrogel. Eng. J. 2012, 16, 15-28. [CrossRef]

22. Wach, R.A.; Mitomo, H.; Nagasawa, N.; Yoshii, F. Radiation crosslinking of methylcellulose and hydroxyethylcellulose in concentrated aqueous solutions. Nucl. Instrum. Methods Phys. Res. Sect. B Beam Interact. Mater. At. 2003, 211, 533-544. [CrossRef]

23. Park, J.-S.; Park, J.-W.; Ruckenstein, E. Thermal and dynamic mechanical analysis of PVA/MC blend hydrogels. Polymer 2001, 42, 4271-4280. [CrossRef]

24. Harsh, D.C.; Gehrke, S.H. Controlling the swelling characteristics of temperature-sensitive cellulose ether hydrogels. J. Control. Release 1991, 17, 175-185. [CrossRef]

25. Tao, X.; Nonaka, H. Wet extrusion molding of wood powder with hydroxy-propylmethyl cellulose and with citric acid as a crosslinking agent. BioResources 2021, 16, 2314-2325. [CrossRef]

26. Xu, Y.; Li, L.; Zheng, P.; Lam, Y.C.; Hu, X. Controllable gelation of methylcellulose by a salt mixture. Langmuir 2004, 20, 6134-6138. [CrossRef]

27. Flory, P.J.; Rehner, J. Statistical mechanics of cross-linked polymer networks II. Swelling. J. Chem. Phys. 1943, 11, 521-526. [CrossRef]

28. Baier Leach, J.; Bivens, K.A.; Patrick, C.W., Jr.; Schmidt, C.E. Photocrosslinked hyaluronic acid hydrogels: Natural, biodegradable tissue engineering scaffolds. Biotechnol. Bioeng. 2003, 82, 578-589. [CrossRef]

29. Gold, G.T.; Varma, D.M.; Taub, P.J.; Nicoll, S.B. Development of crosslinked methylcellulose hydrogels for soft tissue augmentation using an ammonium persulfate-ascorbic acid redox system. Carbohydr. Polym. 2015, 134, 497-507. [CrossRef]

30. Gold, G.T.; Varma, D.M.; Harbottle, D.; Gupta, M.S.; Stalling, S.S.; Taub, P.J.; Nicoll, S.B. Injectable redox-polymerized methylcellulose hydrogels as potential soft tissue filler materials. J. Biomed. Mater. Res. Part A 2014, 102, 4536-4544. [CrossRef]

31. D'Angelo, M.; Benedetti, E.; Tupone, M.G.; Catanesi, M.; Castelli, V.; Antonosante, A.; Cimini, A. The role of stiffness in cell reprogramming: A potential role for biomaterials in inducing tissue regeneration. Cells 2019, 8, 1036. [CrossRef]

32. Wells, R.G. The role of matrix stiffness in regulating cell behavior. Hepatology 2008, 47, 1394-1400. [CrossRef]

33. Munoz-Robles, B.G.; Kopyeva, I.; DeForest, C.A. Surface patterning of hydrogel biomaterials to probe and direct cell-matrix interactions. Adv. Mater. Interfaces 2020, 7, 2001198. [CrossRef]

34. Yamato, M.; Okano, T. Cell sheet engineering. Mater. Today 2004, 7, 42-47. [CrossRef]

35. Nagase, K.; Yamato, M.; Kanazawa, H.; Okano, T. Poly(N-isopropylacrylamide)-based thermoresponsive surfaces provide new types of biomedical applications. Biomaterials 2018, 153, 27-48. [CrossRef]

36. Shi, R.; Bi, J.; Zhang, Z.; Zhu, A.; Chen, D.; Zhou, X.; Zhang, L.; Tian, W. The effect of citric acid on the structural properties and cytotoxicity of the polyvinyl alcohol/starch films when molding at high temperature. Carbohydr. Polym. 2008, 74, 763-770. [CrossRef]

37. Jiang, Q.; Reddy, N.; Zhang, S.; Roscioli, N.; Yang, Y. Water-stable electrospun collagen fibers from a non-toxic solvent and crosslinking system. J. Biomed. Mater. Res. Part A 2013, 101A, 1237-1247. [CrossRef]

38. Oryan, A.; Kamali, A.; Moshiri, A.; Baharvand, H.; Daemi, H. Chemical crosslinking of biopolymeric scaffolds: Current knowledge and future directions of crosslinked engineered bone scaffolds. Int. J. Biol. Macromol. 2018, 107, 678-688. [CrossRef]

39. Stabenfeldt, S.E.; García, A.J.; LaPlaca, M.C. Thermoreversible laminin-functionalized hydrogel for neural tissue engineering. J. Biomed. Mater. Res. Part A 2006, 77A, 718-725. [CrossRef] [PubMed]

40. Martin, B.C.; Minner, E.J.; Wiseman, S.L.; Klank, R.L.; Gilbert, R.J. Agarose and methylcellulose hydrogel blends for nerve regeneration applications. J. Neural Eng. 2008, 5, 221-231. [CrossRef]

41. Payne, C.; Dolan, E.B.; O'Sullivan, J.; Cryan, S.-A.; Kelly, H.M. A methylcellulose and collagen based temperature responsive hydrogel promotes encapsulated stem cell viability and proliferation in vitro. Drug Deliv. Transl. Res. 2017, 7, 132-146. [CrossRef] [PubMed] 
42. Forghani, A.; Kriegh, L.; Hogan, K.; Chen, C.; Brewer, G.; Tighe, T.B.; Devireddy, R.; Hayes, D. Fabrication and characterization of cell sheets using methylcellulose and PNIPAAm thermoresponsive polymers: A comparison Study. J. Biomed. Mater. Res. Part A 2017, 105, 1346-1354. [CrossRef]

43. Bucur, M.; Constantin, C.; Neagu, M.; Zurac, S.; Dinca, O.; Vladan, C.; Cioplea, M.; Popp, C.; Nichita, L.; Ionescu, E. Alveolar blood clots and platelet-rich fibrin induce in vitro fibroblast proliferation and migration. Exp. Ther. Med. 2018, 17, 982-989. [CrossRef]

44. Imashiro, C.; Shimizu, T. Fundamental technologies and recent advances of cell-sheet-based tissue engineering. Int. J. Mol. Sci. 2021, 22, 425. [CrossRef] [PubMed]

45. Kim, H.; Kim, Y.; Park, J.; Hwang, N.; Lee, Y.; Hwang, Y. Recent advances in engineered stem cell-derived cell sheets for tissue regeneration. Polymers 2019, 11, 209. [CrossRef]

46. Yang, J.; Yamato, M.; Kohno, C.; Nishimoto, A.; Sekine, H.; Fukai, F.; Okano, T. Cell sheet engineering: Recreating tissues without biodegradable scaffolds. Biomaterials 2005, 26, 6415-6422. [CrossRef] [PubMed]

47. Wang, H.-B.; Dembo, M.; Wang, Y.-L. Substrate flexibility regulates growth and apoptosis of normal but not transformed cells. Am. J. Physiol. Physiol. 2000, 279, C1345-C1350. [CrossRef]

48. Tilghman, R.W.; Cowan, C.R.; Mih, J.D.; Koryakina, Y.; Gioeli, D.; Slack-Davis, J.K.; Blackman, B.R.; Tschumperlin, D.J.; Parsons, J.T. Matrix rigidity regulates cancer cell growth and cellular phenotype. PLoS ONE 2010, 5, e12905. [CrossRef]

49. Mih, J.D.; Sharif, A.S.; Liu, F.; Marinkovic, A.; Symer, M.M.; Tschumperlin, D.J. A multiwell platform for studying stiffnessdependent cell biology. PLoS ONE 2011, 6, e19929. [CrossRef] [PubMed]

50. Liu, Y.; Li, L.; Chen, X.; Wang, Y.; Liu, M.-N.; Yan, J.; Cao, L.; Wang, L.; Wang, Z.-B. Atomic force acoustic microscopy reveals the influence of substrate stiffness and topography on cell behavior. Beilstein J. Nanotechnol. 2019, 10, 2329-2337. [CrossRef] 